\title{
Stress and depression among students of the last semester in two nursing courses ${ }^{1}$
}

\author{
Danila Perpétua Moreira² \\ Antonia Regina Ferreira Furegato ${ }^{3}$
}

Objective: to identify the presence of stress and depression among final year students of two nursing courses, and the association between these variables. Method: an exploratory-descriptive study, undertaken with final-year students from the Bachelor's degree and Licenciate's degree courses at the Ribeirão Preto College of Nursing, of the University of São Paulo. The Perceived Stress Scale (PSS) and Beck Depression Inventory (BDI) were applied. Results: of the total of 88 participants in the study, $69.8 \%$ have no depression, $18.2 \%$ presented dysphoria, $6.8 \%$ moderate depression, and $5.7 \%$ severe depression, which is a low rate compared to the general population. Medium stress levels were the most frequent (76.9\%). There was no significant statistical difference in the stress score between the two groups of students (Student's t-test: $p=0.295>0.05)$. The data showed a relation between the stress and the presence of indicative signs of depression, especially severe depression (Pearson: r-0.755 and $p<0.01$ ). Discussion: The majority did not show signs of depression. The depressive states found among the students on the two courses accompanied proportionately those who obtained high stress scores, as recorded by other studies on this issue. Conclusion: Students with higher levels of stress are more prone to present depression, deserving educators' attention.

Descriptors: Stress; Depression; Nursing; Undergraduate.

\footnotetext{
1 This research was supported by Conselho Nacional de Desenvolvimento Científico e Tecnológico (CNPq), process \# 302579/2009-5. 2 RN. Scholarship holder of the Scientific Initiation Program at the Conselho Nacional de Desenvolvimento Científico e Tecnológico (CNPq). Escola de Enfermagem de Ribeirão Preto, Universidade de São Paulo, WHO Collaborating Centre for Nursing Research Development, Brazil.

${ }^{3}$ PhD, Full Professor, Escola de Enfermagem de Ribeirão Preto, Universidade de São Paulo, WHO Collaborating Centre for Nursing Research Development, Brazil.
} 


\section{Estresse e depressão entre alunos do último período de dois cursos de enfermagem}

Objetivo: identificar a presença de estresse e depressão entre estudantes do último ano de dois cursos de enfermagem e a associação entre essas variáveis. Método: estudo exploratório descritivo, realizado com alunos do último ano dos cursos de bacharelado e licenciatura da Escola de Enfermagem de Ribeirão Preto da Universidade de São Paulo. Aplicou-se Escala de Estresse Percebido-EEP e Inventário de Depressão de Beck-IDB. Resultados: dos 88 sujeitos da amostra, 69,8\% não apresentaram sinais de depressão, 18,2\% apresentaram disforia, 6,8\% têm depressão moderada e $5,7 \%$ depressão grave, índice baixo, em relação à população geral. Níveis médios de estresse foram os mais frequentes $(76,9 \%)$. Não houve diferença significativa nos escores de estresse entre os dois grupos de alunos ( $t$ de Student: $p=0,295>0,05$ ). Os dados revelaram relação do estresse com a presença de sinais indicativos de depressão, especialmente na depressão grave (Pearson: $r-0,755$ e $p<0,01$ ). Discussão: a maioria não apresentou sinais de depressão. Os estados depressivos, entre os estudantes dos dois cursos de enfermagem, acompanham proporcionalmente aqueles que obtiveram escores elevados de estresse, tal como registrado em outros estudos dessa temática. Conclusão: alunos com maiores níveis de estresse estão mais sujeitos a apresentarem depressão, merecendo a atenção dos educadores.

Descritores: Estresse; Depressão; Enfermagem; Estudantes.

\section{El estrés y la depresión entre los estudiantes de ultimo periodo de dos cursos de enfermería}

Objetivo: Identificar la presencia de estrés y depresión entre estudiantes del ultimo año de dos cursos de enfermería y la asociación entre estas variables. Método: Estudio exploratorio, realizado con alumnos del último año de dos cursos de pregrado en la Escuela de Enfermería de Ribeirão Preto, de la Universidad de São Paulo. Se aplicó la Escala de Estrés PercibidoPSS y el Inventario de Depresión de Beck-BDI. Resultados: De los 88 sujetos de la muestra, $69,8 \%$ no mostró señales de depresión, 18,2\% tenía disforia, 6,8\% con depresión moderada y $5,7 \%$, depresión severa, puntuación baja en relación a la población general. Los niveles medios de estrés fueron los más frecuentes (76,9\%). No hubo diferencias significativas entre los escores de estrés de los dos grupos de estudiantes ( $t$ de Student: $p=0,295>0,05$ ). Los datos muestran relación del estrés con la presencia de señales de depresión, especialmente en la depresión grave (Pearson: r-0, 755 y p <0,01). Discusión: La mayoría no mostró signos de depresión. Los estados depresivos, entre los estudiantes de los dos cursos de enfermería, coinciden con los que obtuvieron puntajes altos de estrés, como se ha encontrado en otros estudios sobre este tema. Conclusión: Los alumnos con mayores niveles de estrés son más propensas a experimentar depresión, mereciendo la atención de los educadores.

Descriptores: Estrés; Depresión; Enfermería; Estudiantes.

\section{Introduction}

Stress was studied and understood as a biological response in the nineteen-thirties, by the Canadian endocrinologist Hans Selye, who defined it as a complex of adaptive reactions of the body to new limits - that is, it is the response of impotence in the face of a decline of resources necessary for overcoming a specified demand. He described the biochemical reactions which occur in the organism in the presence of stress. These take place in the pituitary-hypothalamus-adrenal system with the release of hormones that act by altering the metabolism, so that the organism can defend itself against the process of stress. Thus, the individuals respond to stress differently, due to variations in personality, previous experiences, genetic characteristics and specific social factors ${ }^{(1-2)}$.

Negative and persistent stress, Burnout, may involve various unwanted physical manifestations, such as increased blood pressure and a greater susceptibility to cerebro-vascular accidents (CVA). Infection due to 
reduced immunological response is frequent, as are gastrointestinal disorders such as diarrhea and constipation, eating disorders, weight gain or loss and insulin resistance, associated with type 2 diabetes and exacerbation of diabetes; it may also lead to tension-type headaches, insomnia, reduction in sexual desire and temporary impotence in men, and exacerbation of premenstrual tension in women, reduction in concentration, inhibition of learning and reduction in memory, as well as exacerbation of skin lesions. This set of prejudicial alterations comprises affected person's quality of life ${ }^{(1-4)}$.

Depression is a severe disturbance of mood, being the fourth leading cause of social incapacitation in the world. One in every twenty people is struck by depression at some point in their lives. Of every fifty cases, one will require hospitalization, and $15 \%$ of these will commit suicide. The beginning of depression is most frequent between the ages of 20 to 50, but the average age for its identification is approximately forty, for $50 \%$ of the patients. It is considered a public health problem in view of its social costs which involve drops in productivity (in studies or work), mood changes, cognitive, psychomotor and vegetative alterations, loss of initiative, and apathy ${ }^{(5-9)}$.

Can stressful events be related to depression? The depressive episode may be associated with a recent stressful event. The risk factors most associated with depression are family history, events in infancy, aspects related to personality, social isolation and unpleasant experiences in daily life. The combination of genetic factors, stress in early age and continuous stress can determine a person's vulnerability to psychiatric disorders such as depression. Stressors linked directly to self-esteem are more likely to advance depression and thus each person judges the stressful agent as serious or not, depending on the idiosyncratic meanings which it is given ${ }^{(9-10)}$.

Professions which demand close contact with people and which are charged with affective involvement - such as medicine, psychology, nursing and physiotherapy are more likely to develop stress at work and Burnout syndrome ${ }^{(11-14)}$.

Nursing is one of these stressful professions, and from the academic training onwards, the student runs into situations which require the taking of important decisions for patient care; the insecurity and anxiety which result from this process may cause or worsen stress. Characteristics such as a high level of cognitive skills and proactive disposition and attitudes are constantly required, both among nurses working in practice and nursing students. In this way, stress and depression may prejudice the performance both of student nurses and qualified nurses ${ }^{(12-17)}$.

Considering this, the recognition of stress in student nurses is important, such that there are preventive measures and strategies aiming to reduce the predisposing factors of stress, minimizing its consequences for nurses' health and the performance of their daily activities.

\section{Objective}

To identify the presence of stress and indicative signs of depression in students in the last semester of two undergraduate nursing courses, and to compare them, seeking associations between these variables.

\section{Method}

This is an exploratory-descriptive study, whose research was carried out in the Ribeirão Preto College of Nursing (University of São Paulo) with the students studying in the last semester of two undergraduate nursing courses (Bachelor's degree - daytime and Licenciate's degree - evening and night). These courses both aim to train general nurses, able to provide care for individuals, families, and community groups, or to act in health promotion in basic education, and as teachers on vocational training courses in nursing. Both courses take place with a view to health promotion, prevention of and recovery from illnesses, and studies which can respond to emerging health issues in Brazil.

Two instruments were used for obtaining this study's data:

1-The Perceived Stress Scale - PSS-10 was translated and validated for Brazil in two stages, with the participation of 793 subjects. It is composed of 14 items with response options varying from zero to four $(0=$ never; $1=$ almost never; 2=sometimes; 3 =almost always; 4=always). The questions with positive connotations $(4,5,6,7$ 9,10 and 13) have their score added up in inverted order. The remaining questions are negative and are to be summed directly. The sum of the questions' scores can vary from zero to 56 . It is a general scale which can be used with various age groups, as it does not contain context-specific questions ${ }^{(18)}$.

2-The Beck Depression Inventory (BDI), a selfevaluation depression scale, widely used in clinical practice and in tracking studies, validated for Portuguese in the nineteen-sixties. It contains 21 statements about sadness, pessimism, feelings of failure, lack of satisfaction, feelings of guilt, feelings of punishment, 
self-deprecation, self-accusations, suicidal ideas, bouts of crying, irritability, social withdrawal, indecision, distortion of body image, work difficulties, sleep disturbances, fatigue, loss of appetite, weight loss, excessive concerns about themselves and reduction of libido. The degree of intensity varies from 0 to 3 , in each statement. The Center for Cognitive Therapy recommends as cut-off points for tracking: $<15=$ normal, 15-19=dysphoria, $>20=$ moderate depression, and $>30=$ severe depression ${ }^{(19)}$.

The BDI contains a header with questions referring to date, group, subject code, age, sex, marital status and religion.

In accordance with Resolution 196/96 of the Brazilian Ministry of Health's National Council of Health, this project was approved by the Ribeirão Preto College of Nursing (University of São Paulo) Research Ethics Committee (1352/2011).

Data was collected in a classroom by a scientific research scholarship student, with supervision from the lecturer. A time was chosen during October 2011 for each of the courses, taking into account the possibility of there being few students absent. The students were duly informed about the research's objective, and the instruments were applied after the students had signed the Terms of Free and Informed Consent. Of the 114 final year students matriculated on the two nursing courses, $88(77.2 \%)$ participated in the research, of whom $52(65 \%)$ were from the 80 in the $4^{\text {th }}$ year of the Bachelor's degree, and 36 (72\%) were from the 50 from the $5^{\text {th }}$ year of the Licenciate's degree in nursing; 26 students were not in class on the day of data collection in their class.

The data was tabulated in the SPSS - Statistical Package for the Social Sciences, version 13.0 for Windows. To compare the categorical results between subgroups, the Chi-squared test was used, while to compare the stress and depression scores in the entire group and the separated groups, the Pearson correlation coefficient was used. The tests' statistics were considered significant when the $p$ value was inferior to 0.05 . The results were analyzed and discussed in line with the literature on the theme of this issue.

\section{Results}

A total of 88 undergraduate students took part in the study, of whom 52 were from the Bachelor's degree daytime course (B), and 36 from the Licenciate's degree evening course in nursing.
On the Bachelor's degree course, the lowest age of the students was 21, the highest was 25, and the average age was 22.5 years old. The standard deviation was 1.07 . The greatest concentration was between 21 and 23 years of age $(78 \%)$.

On the Licenciate's degree course, the age varied from 21 to 33 years, with the greatest concentration between 24 and 30 years (64.5\%). The average age was 24.8 years, with a standard deviation of 2.6 years. In the Bachelor's degree course, $28.8 \%$ of the subjects did not respond to the item corresponding to age, while on the Licenciate's degree course, $13.8 \%$ opted not to reveal their age.

The majority of participants in both nursing courses were female $(B=96.2 \%$ and $L=97.2 \%$ ). The predominant marital status was single $(B=93.9$ e $L=91,7 \%)$. The majority of the students were Catholic $(B=64.3 \%$ and $L=84.6 \%$ ), followed by Spiritualists ( $B=19 \%$ and $\mathrm{L}=15.4 \%$ ); the remaining participants were Protestants; 12 subjects did not fill out this item.

From the 21 questions in the Beck Depression Inventory, the authors were able to identify if the respondents had signs of depression, depending on whether they scored over 15 points ${ }^{(19)}$.

Therefore, $73.1 \%$ of the Bachelor's degree students and $63.9 \%$ of the Licenciate's degree students did not present signs of depression. Eight of the Bachelor's degree students (15.4\%) scored between 15 and 19, being classified as dysphoria or moderate depression; four $(7.7 \%)$ scored between 20 and 29, being classified as moderate depression and two students (3.8\%) were over 30 points, indicating severe depression.

On the Licenciate's degree course, the presence of dysphoria was identified in 8 students (22.3\%), moderate depression was found in two students (5.6\%) and three students $(8.4 \%)$ scored 30 or more points, indicating the presence of severe depression.

Table 1 - Distribution of frequency of depression among students on two nursing courses. Ribeirão Preto, SP, Brazil, 2011

\begin{tabular}{|c|c|c|c|c|c|c|}
\hline \multirow{3}{*}{ Depression levels } & \multicolumn{6}{|c|}{ Nursing Courses } \\
\hline & \multicolumn{2}{|c|}{$\begin{array}{l}\text { Bachelor's } \\
\text { degree }\end{array}$} & \multicolumn{2}{|c|}{$\begin{array}{l}\text { Licenciate's } \\
\text { degree }\end{array}$} & \multicolumn{2}{|c|}{ Total } \\
\hline & $\mathbf{N}$ & $\%$ & $\mathbf{N}$ & $\%$ & $\mathbf{N}$ & $\%$ \\
\hline No depression & 38 & 73.1 & 23 & 63.9 & 61 & 69.3 \\
\hline Dysphoria & 8 & 15.4 & 8 & 22.2 & 16 & 18.2 \\
\hline Moderate depression & 4 & 7.7 & 2 & 5.6 & 6 & 6.8 \\
\hline Severe depression & 2 & 3.8 & 3 & 8.3 & 5 & 5.7 \\
\hline Totals & 52 & 100 & 36 & 100 & 88 & 100 \\
\hline
\end{tabular}


From the results it may be observed that there was no significant difference in the general results between the courses, although the cases of severe depression were more frequent among the students on the Licenciate's degree course, as may be seen in Table 1.

The results of the students' responses to the Perceived Stress Scale showed that the majority (73.9\%) presented a medium level of stress, considering the following scores: from 0 to 18.6 = low level of stress, between 18.7 and 37.2 = medium level of stress and, from 37.3 onwards, high levels of stress. Among these scores, only $9.1 \%$ of the students were in a comfortable situation, that is, with low stress levels. 17 students were among the most stressed, of whom 8 were from the Licenciate's degree course, and 7 from the Bachelor's degree. Due to the size difference between the two groups, the eight from the Licenciate's degree course represented $22 \%$, while the seven from the Bachelor's degree course represented $13.5 \%$.

Figure 1 shows the relationship between stress levels and the presence of signs indicating depression in the two groups of students. Table 2 gives the results of the tests for correlation between these results.

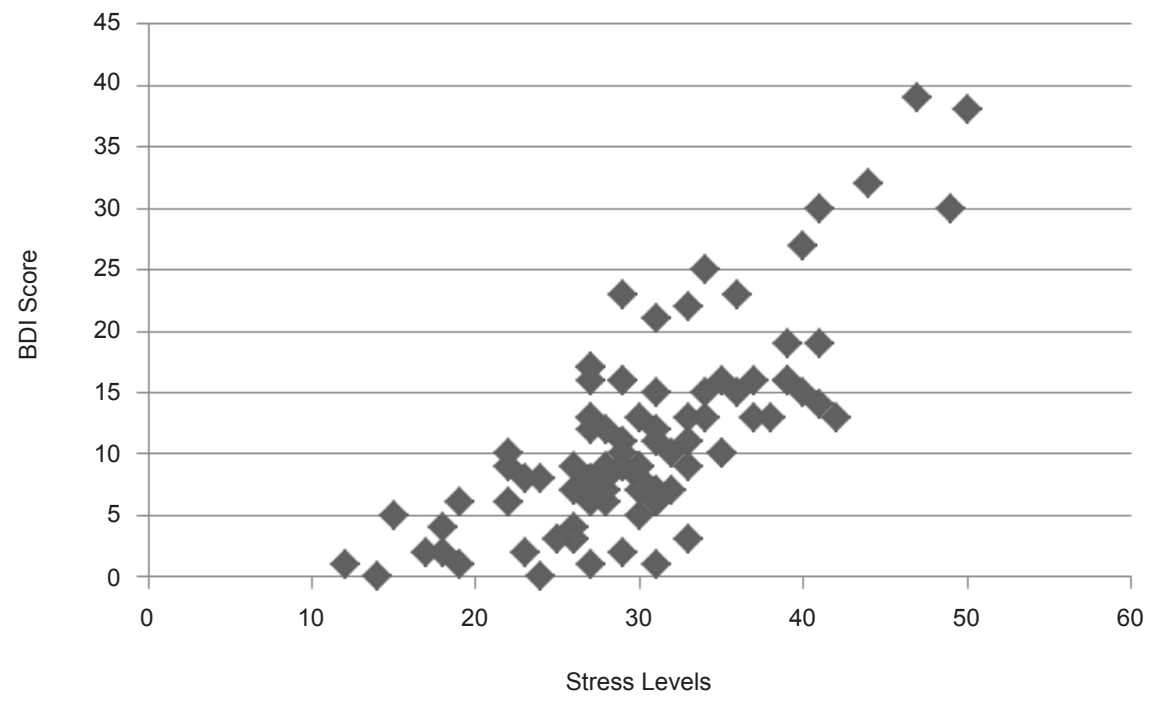

Figure 1 - Correlation between stress levels and the presence of signs indicating depression among students in the final semester in two nursing courses

According to the data presented in Figure 1, one may observe the relationship between stress and depression, suggesting that stress levels significantly influence the severity of the depressive state.

Table 2 - Correlation between the results of the tests for depression and stress among students in the final semester of two nursing courses $(n=88)$. Ribeirão Preto, SP, Brazil, 2011

\begin{tabular}{lccc}
\hline & Tests & Total Depression & Total Stress \\
\hline \multirow{2}{*}{ Depression } & Pearson Correlation & 1.0 & $0.755^{\star *}$ \\
& p-value (two sided) & 0.000 & 0.000 \\
\multirow{2}{*}{ Stress } & Pearson Correlation & $0.755^{\star *}$ & 1.0 \\
& p-value (two sided) & 0.000 & 0.000 \\
\hline
\end{tabular}

On carrying out the Student t-test, $\mathrm{p}=0.295>0.05$ was obtained. Therefore, there was no statisticallysignificant difference in the stress levels' average scores among the two courses. However, in Table 2 a significant correlation may be observed between the scores for stress and depression in these groups $(r=0.755)$, that is, a strong and significant correlation.

\section{Discussion}

The profile found in this study's sample does not present characteristics which deserve highlighting, as has been reported in other studies involving student nurses. Neither were there found data which stood out in the comparison of the two groups' profiles, such that the average ages in the groups were close, as were the frequencies for sex and other indicators ${ }^{(12,20-23)}$. 
For the young nursing students - as with medical students - the last year of their training involves the experience of the transition from academic life to work life, which is accompanied by an increase in highlydemanding tasks with a high degree of responsibility, raising tensions and anxiety. In the final year, the workload of study and placements puts the student in a condition of great vulnerability. One of the reasons for the final-year students' worry may be the feeling of unpreparedness for the job market, as they are practically professionals and may feel fear at the prospect of working alone in the near future, without the lecturer's support. This process is often accompanied by competitiveness among their own colleagues. In addition to this, for the women, the career (professional or academic) is added to by personal, biological, hormonal, sexual and social demands(17,20-21,24-25).

The transition from the academic period to professional life involves important personal decisions, such as whether to return to one's hometown or face life in the big city, as well as starting work, starting a family, and taking on financial responsibilities. Thus, leaving the protected atmosphere of academia and facing the new challenges may cause stress and, as a consequence, emotional imbalance and depressive states. Thus it was that the vast majority of the subjects of the research were suffering from medium-level stress, with a slight tendency (non-significant) for more among the Licenciate's degree students.

The workplace atmosphere, in the widely-varying fields in the area of health, may be stressful, bearing in mind that the safety of the patient and the security of the nurse's job both depend on the quality of the care that the nurse provides. In addition, the lack of predictability of many situations in which the health professional has to make choices and carry out effective actions demands a high level of technical-scientific competency. This atmosphere, when perceived as a threat, may bring biopsycho-social consequences, should the nurse's coping ability prove inadequate ${ }^{(1,3,14,21)}$.

A recent study undertaken in Portugal also determined that nurses, at the start of their careers, have high stress levels, generally resulting from difficulties in interpersonal relationships between the workers, as well as problems with the structure and organization of the work setting(13).

In the present study it was observed that the states of dysphoria, moderate depression and -especially severe depression were present among the final year students on the two nursing courses, corresponding to the people who obtained high stress scores. This corroborates other studies on the issue $\mathrm{e}^{(13,21,23)}$.

One study which related depression among medical students to the stress caused by demands during the undergraduate course found, among the causes, the high volume of new information, the shortage of time for leisure and social activities, and the onus of contact with situations which require emotional components such as the illness and death of patients ${ }^{(14)}$.

People with dysphoria or other levels of depression present a persistent instability of mood which may be manifested in states of depression or excitement, causing difficulties in performing their personal or professional tasks. Although dysphoria is not serious enough to meet the diagnostic criteria for a depressive disorder, such individuals must be observed and directed to seek medical assistance, as well as being encouraged to talk about what is afflicting them with professionals able to help them with coping measures ${ }^{(5-6)}$.

However, the indication of the possibility of a professional being diagnosed as moderately - or, more importantly - severely depressed deserves the attention of the person in question and his or her lecturers (in the case of students) or managers (in the different health services).

A study undertaken in three Brazilian state capitals (Brasília, São Paulo and Porto Alegre) showed that in the general population there was a prevalence of depression of $1.5 \%, 1.3 \%$ and $6.7 \%$, respectively. Comparing that study's data with the results found among the final-year nursing students from the two courses, the situation may appear worrying, as $26.4 \%$ of the Bachelor's degree students and $36.1 \%$ of the Licenciate's degree students had signs indicating depression. When one considers that the prevalence of manifestation of depression in the population aged from 20 to 40 years of age is approximately $25 \%$, it may be observed that the present study's results are close to these limits. However (and fortunately) the majority of the subjects (69.3\%) do not present signs of depression and $18.2 \%$ have slight signs of depression, which totals $87.5 \%$ of the students in a good situation. The $12.5 \%$ who deserve greater care are the cases of students with signs of moderate $(6.8 \%)$ or severe $(5.7 \%)$ depression, which is compatible with other studies on this issue ${ }^{(7,9,14,21)}$.

A study which aimed to identify the presence of depression, self-evaluation of health and other associated factors in second-year nursing students found that $15.4 \%$ of Bachelor's degree students and $28.6 \%$ of Licenciate's degree students had indications of depression, with 
$14 \%$ of the total having signs of moderate and severe depression. In the group in question, it was determined that there was a relationship between depression and quality of life, and that perception of one's own health is an important indicator for the presence of depression ${ }^{(20)}$.

It is noteworthy that the subjects of this study were informed about the research's results. The cases identified were sought out, listened to and advised by the lecturer responsible, on the subject of the personal and professional importance of seeking help from a specialist.

These results confirm the need for programs which help to minimize stress and identify the presence of depression among students. Programs which use meditation, hypnosis and physical relaxation techniques, and support groups for expressing emotions or discussing everyday problems may increase immunity to symptoms of stress and depression(1,14,22,25). This personal learning may also support the professional in the future in helping patients who present problems resulting from stress and depression.

\section{Conclusion}

The transition from the academic period to the new phase of professional activity, where the young people need to take important decisions, contributes to the presence of stress, as observed in the present study.

This study, undertaken with two groups of student nurses in the final semester of their courses, showed that stress may be related to the presence of symptoms of depression. The scores for stress were proportionate to the scores for depression, that is, the greater the stress the student presented, the more susceptible he or she would be to presenting signs of depression.

Bearing in mind the results found, one should note the need for the attention of educators and the creation of programs with preventive and therapeutic actions, based on which the students may reflect and find healthy solutions for their distress, and use the knowledge acquired in their future performance of their duties.

\section{Acknowledgements}

To Dr. Claudia dos Santos and Dr. Benedicta Miyeko Hayashida for statistical assistance and descriptive data analysis of this research.

\section{References}

1. Everly GS Jr, Lating JM. A clinical guide to the treatment of the human stress response. Book Series:
The Plenum Series on Stress and Coping. Springer: NY (USA); 2002.

2. Rossi AM, Perrewe PL, Sauter, ST. Stress e qualidade de vida no trabalho: perspectivas atuais da saúde ocupacional. São Paulo: Atlas; 2007.

3. Benevides Pereira AMT, organizador. Burnout: quando o trabalho ameaça o bem estar do trabalhador. São Paulo: Casa do Psicólogo; 2002.

4. Rosch PJ. Genes and stress cause coronary atherosclerosis not saturated fat. Lancet. 2010;375(9728):1780-81.

5. Del Porto JA. Depressões. São Paulo: EPM- Projetos Médicos; 2005.

6. Justo LP, Calil HM. Depression - does it affect equally men and women? Rev Psiq Clín. 2006;33(2):74-9.

7. Menezes PR, Nascimento AF. Epidemiologia da depressão nas diversas fases da vida. Porto Alegre (RS). ARTMED; 2000.

8. Almeida N Fo, Lessa I, Magalhães L, Araujo MJ, Aquino E, James S, Kavachi I. Social inequality and depressive disorders in Bahia, Brazil: interactions of gender, ethnicity and social class. Soc Sci Med. 2004;59(7):1339-53.

9. Fráguas Jr R, Alves TCTF. Depressão no hospital geral: estudo de 136 casos. Rev Assoc Med Bras.2002;48(3):225-30.

10. Dormann C, Zapf D. Social stressors at work, irritation, and depressive symptoms: accounting for unmeasured third variables in a multi-wave study. J Occup Organ Psychol. 2002;75(1):33-58.

11. Ribeiro RP, Martins JT, Marziale MHP, Robazzi MLCC. Work-related illness in nursing: an integrative review. Rev Esc Enferm USP. 2012;46(2):495-504.

12. Fanco Jr GP, Barros ALBL, Nogueira-Martins LA, Zeitoun SS. Burnout in nursing residents. Rev Esc Enferm USP. 2012;45(1):12-18.

13. Rodrigues VM, Ferreira ASS. Stressors in nurses working in Intensive Care Units. Rev. Latino-Am. Enfermagem. 2011;19(4):1025-32.

14. Zonta R, Robles ACC, Grosseman S. Stress coping strategies developed by medical students of the Federal University of Santa Catarina. Rev Bras Educ Med. 2006;30(3):147-53.

15. Batista KM, Bianchi ERF. Stress among emergency unit nurses. Rev. Latino-Am. Enfermagem. 2006;14(4):534-9. 16. Lorenz VR, Benatti MCC, Sabino MO. Burnout and stress among nurses in a university tertiary hospital. Rev. Latino-Am. Enfermagem. 2010;18(6):1084-91.

17. Costa ALS. Estresse em estudantes de enfermagem: construção dos fatores determinantes. REME Rev Min Enferm. 2007;11(4):414-9. 
18. Reis RS, Hino, AAF, Añez CRR. Perceived Stress Scale: reliability and validity study in Brazil. J Health Psychol. 2010;15(1):107-14. DOI:10.1177/1359105309346343 19. Gorenstein C, Andrade LHSG, Zuardi AW (eds). Escalas de avaliação clínica em psiquiatria e psicofarmacologia. São Paulo: Lemos; 2000.

20. Furegato ARF, Santos JLF, Silva EC. Depression among students from two nursing undergraduate programs: self-assessment on health and associated factors. Rev Bras Enferm. 2010;63(4):509-16.

21. Santos VEP, Radünz V. Stress in nursing students and patient safety. Rev Enferm UERJ. 2011;19(4):616-20.

22. Li, Mh. Helping college students: Identifying predictors of active coping in different stressful situations. J Psych, Psychol, Ment Health. 2008;2:1-15. 23. Garro IMB, Camilo SO, Nóbrega MPSS. Depressão em graduandos de enfermagem. Acta Paul Enferm. 2006;19(2):162-7.

24. Aube J, Fleury J, Smetana J. Changes in women's roles: impact on and social policy implications for the mental health of women. Rev Psychopatol. 2000;12:633-56.

25. Peterson U, Bergstrom G, Samuelsson M, Åsberg M, Nygren A. Reflecting peer- support groups in the prevention of stress and burnout: randomized controlled trial. J Adv Nurs. 2008;63:506-16. 